\title{
Antibody response to the epsilon toxin of Clostridium perfringens following vaccination of Lama glama crias
}

\author{
Adriana B. Bentancor ${ }^{1}$, Pablo Halperin ${ }^{2}$ Myriam Flores $^{3}$, Fabián Iribarren ${ }^{4,5}$ \\ ${ }^{1}$ Microbiología, ${ }^{2}$ Histología, ${ }^{3}$ Estadística, ${ }^{4}$ Enfermedades Infecciosas, Facultad de Ciencias Veterinarias Universidad de Buenos \\ Aires, Argentina, Chorroarín 280. Cdad. Autónoma de Buenos Aires, Argentina \\ ${ }^{5}$ Instituto Rosenbusch SA
}

\begin{abstract}
Background: Enterotoxaemia produced by Clostridium perfringens A, C and D is an important cause of mortality in young llamas. There is no data on antibody responses following vaccination with epsilon toxin.

Methodology: Twenty-six L. glama crias were divided into four groups which were vaccinated with a commercial vaccine (Mancha Gangrena Enterotoxemia, Instituto Rosembusch Sociedad Anónima, Argentina) on days 0, 21 and 42 or left as unvaccinated controls. An indirect ELISA was compared with the mouse neutralization test (MNT) for measuring titers to C. perfringens type D epsilon toxin and used to determine titers in sera taken before vaccination and $16,28,49,59$, and 93 days later.

Results: The ELISA gave comparable results to the MNT and showed animals vaccinated once failed to develop raised titers. A week following a second vaccination, mean antibody titers rose significantly $(\mathrm{P}<0.05)$ and $7 / 12$ animals developed high titers which were present in only one animal at the end of the study (day 93). A third vaccination resulted in a decrease in mean antibody titers a week later.

Conclusions: Llamas develop antibodies to Clostridium perfringens type D epsilon toxin after two vaccinations at a 21-day interval. Further studies are indicated to determine if these inoculations protect against enterotoxemia and the most appropriate vaccination schedule.
\end{abstract}

Keywords: Lama glama, C. perfringens type D epsilon toxin, antibodies, vaccine

J Infect Dev Ctries 2009; 3(8):624-627.

Received 17 February 2009 - Accepted 3 July 2009

Copyright $\odot 2009$ SBentancor. This is an open-access article distributed under the Creative Commons Attribution License, which permits unrestricted use, distribution, and reproduction in any medium, provided the original work is properly cited.

\section{Introduction}

For many years, llamas (Lama glama) have been a source of meat, milk, fibre and fuel, and have served as beasts of burden. Studies in the United Kingdom showed $4-11 \%$ of llama deaths were in animals under six months old (crias) with a high proportion occurring in the first week of life [1]. Enterotoxemia caused by Clostridium perfringens is a major cause of mortality in neonatal llamas [2-4] and type D organisms have been found in llamas in Argentina [5]. The disease is most common in South American Camelids after periods of rain when the pastures revive and the increased protein leads to intestinal flora becoming more Gram + and the PFU of $\mathrm{C}$ perfringes increasing per gram of faeces. The bacteria produce a protoxin that is cleaved by trypsinproteolytic enzymes to the active epsilon toxin which increases GTPc and ATPc, thereby increasing the permeability of the intestinal cells. The toxin also enters the blood and injures the central nervous system [6]. While commercial vaccines against enterotoxemia using epsilon toxoid adsorbed onto an adjuvant (usually aluminum hydroxide) have been found to be highly effective in preventing the disease in sheep $[7,8]$ and to a more variable extent in goats [9], there is no data on their use in llamas $[4,10]$. In this report we describe the characterization of the IgG responses of llamas to vaccination with a commercial vaccine against enterotoxemia.

\section{Material and methods}

\section{Animals and experimental design}

The experimental animals were part of an extensive breeding herd in 9 de Julio, Buenos Aires, Argentina. Twenty-six apparently healthy crias (young animals), three to five months old, were selected for the trial; at this age colostral $\mathrm{IgG}$ can no longer be detected [11]. The animals were arbitrarily assigned to four groups: unvaccinated controls (7); vaccinated once on day 0 (7); vaccinated twice on days 0 and 21 (6); and vaccinated three times on days 0, 21 and 42 (6). Animals were given weekly health checks for the duration of the study. 


\section{Sampling}

Sera were obtained from blood samples collected from the jugular veins of animals on days $0,16,28$, 49,59 and 93 . The sera were stored at $-20^{\circ} \mathrm{C}$ until used in ELISAs.

\section{Vaccine}

A combined gangrene, black leg, and enterotoxaemia vaccine (Mancha Gangrena Enterotoxemia, Instituto Rosenbusch Sociedad Anónima, Argentina) was used in our study. The enterotoxaemia component of the vaccine is an ultrafiltered inactivated $C$. perfringens type $\mathrm{D}$ toxin adsorbed onto an aluminium salt. The vaccine was injected subcutaneously over the shoulder using an aseptic technique.

\section{Indirect ELISA}

To determine if indirect ELISAs on llama sera give reproducible estimates of antitoxin levels that correlate well with the conventional in vivo toxin neutralization test in mice [12], sera from one llama vaccinated on days 0 and 16 and sampled on days 0 , 16 and 47 were tested using the mouse neutralisation test (MNT) and ELISA. Thirty albino mice each weighing about $22 \mathrm{~g}$ were used in the MNT. Serial dilutions of the sera from the llama were made in PBS-Tween20 (1:2 to $1: 256)$ and incubated with epsilon toxin (previously titrated) at $37^{\circ} \mathrm{C}$ for 60 minutes before being inoculated intra-peritoneally into mice, two mice for each dilution, following the method in the British Pharmacopeia 2007 (BPVet2007). Numbers of dead mice were recorded at 48 hours.

The ELISA assay was performed as described previously [12] using epsilon toxin $(50 \mathrm{IU} / \mathrm{ml})$ diluted 1:3200 in carbonate buffer $(\mathrm{pH} 9,6)$ (Instituto Rosenbusch SA de Biologia Experimental Agropecuaria, Buenos Aires, Argentina) and incubated in polystyrene-96 well ELISA plates (Maxisorb, NUNC) $(100 \mu \mathrm{l} /$ well $)$ for five days at 4 $8^{\circ} \mathrm{C}$. After three washes with $200 \mu \mathrm{l}$ PBS Tween, test and control sera diluted 1:100 in PBS were added and incubated for 60 minutes at $37^{\circ} \mathrm{C}$. C. perfringens D rabbit-antitoxin (Lot $\mathrm{N}^{\circ}$ IRP249 United States Department of Agriculture) diluted in PBS to 10 $\mathrm{IU} / \mathrm{ml}$ was used as a positive control and normal rabbit serum as a negative control. Following three washes in PBS Tween, Protein A conjugated to horse radish peroxidase (Protein A HRP, Sigma, batch 106 H82 80, USA) which is known to detect IgG of llamas [11,13], was added and incubated for one hour.
Following three washes in PBS Tween, the TMB/ $\mathrm{H}_{2} \mathrm{O}_{2}$ substrate $\left(3,3^{\prime}, 5,5^{\prime}\right.$ '-tetramethylbenzidine dihydrochloride, Sigma, USA) was added and the reaction stopped after five minutes with $\mathrm{H}_{2} \mathrm{SO}_{4}(0,5$ $\mathrm{N})$. Color was measured with an Elisa reader at OD $450 \mathrm{~nm}$ and the results expressed in $\mathrm{IU} / \mathrm{ml}$, using the equation [12]:

Ant. Concentration $=\frac{\left(O D_{\text {sample }}-O D_{\text {neg control }}\right) \times 100}{O D_{\text {positive control } 10 U \mathrm{UI}}-O D_{\text {neg control }}}$

As in the case of goats [9], a llama was categorized as having a high antibody titer if the antibody level was over $0.25 \mathrm{IU} / \mathrm{ml}$.

\section{Statistical methods}

Analysis was conducted with the OD logarithm transformation of repeated measures in time together with a completely randomized design, considering the llama as an experimental unit undergoing treatment (doses with four levels, group 1-3 and control) and repeated over a 93-day schedule (with 6 levels: $0,16,28,49,59$ and 93 days). Means transformed responses of the four treatments were analyzed using Scheffe test [14]. The software used was InfoStat, 2009.

\section{Results}

Vaccinated animals remained healthy for the duration of the study and all recorded weight gains.

There was a significant linear relationship $(\mathrm{r}=$ 0,9977) (P 0,95) between LD50 values in the MNTs (C. perfringens epsilon antitoxin levels $0 \mathrm{IU} / \mathrm{ml}, 8,3$ $\mathrm{IU} / \mathrm{ml}$ and $5,53 \mathrm{IU} / \mathrm{ml}$ on days 0,16 and 47 respectively) and the ELISA OD values $(0,11,2,16$ and 0,93 on days 0,16 and 47 respectively).

The antibody titers in the animals studied are shown in table 1 . The antibody titers at the start of the trial were essentially the same in all groups $(p>0.05)$ with none of the animals having high titers. The antibody levels were also similar 16 days after the first vaccination although 3/19 animals developed high titers. Following the second vaccination at 21 days, increased mean antibody titers were detected at day 28 in both groups of vaccinated animals with 7/12 animals vaccinated twice developing high titers. Mean antibody levels continued to rise and were further increased at day 49 in the animals that received only two doses of vaccine. Animals receiving a further vaccine at day 42, however, showed a decrease in antibody titer at day 49 . While 
$6 / 6$ of the animals vaccinated twice had high antibody titers at day 49 , only $1 / 6$ of the animals vaccinated other commercial vaccines and the most appropriate vaccination intervals.

Table 1

\begin{tabular}{|c|c|c|c|c|}
\hline Day & Unvaccinated & 1- dose group & 2-doses group & 3-doses group \\
\hline 0 & $0,12 \pm 0,01$ & $0,12 \pm 0,01$ & $0,13 \pm 0,01$ & $0,13 \pm 0,01$ \\
\hline 16 & $0,12 \pm 0,01$ & $0,13 \pm 0,02$ & $0,16 \pm 0,05$ & $0,14 \pm 0,04$ \\
\hline & & & & $0,22 \pm 0,1$ \\
\hline \\
49
\end{tabular}

three times had high titers. In all groups of vaccinated animals, the mean antibody titers declined up to the end of the study on day 93 when only $1 / 20$ vaccinated animals had a high titer (an animal vaccinated twice).

Through comparison of mean values of variable transformed response by pairs, we found that the group vaccinated twice differed significantly from both the unvaccinated group and the group vaccinated once $(p<0.05)$. No other differences were found among compared pairs. When multiple comparisons between the 24 corresponding dose-day values were made with the Scheffe test (data not shown), the highest response was observed at day 49 in the group vaccinated twice $(\mathrm{p}<0.05)$, one week after the second vaccination.

\section{Discussion and conclusions}

Our results show that the ethically, economically and technically more acceptable ELISA is comparable to the MNT in detecting antibodies in llama sera to $C$. perfringens epsilon toxin. Further, we show that llamas exhibit no apparent side effects following vaccination with a commercial vaccine and that they develop antibodies to the $C$. perfringens epsilon toxin. Animals vaccinated once did not develop significant titers but those vaccinated twice, on days 0 and 21, developed titers regarded as high in other species (6/6 by day 49). Further studies are indicated to determine if these titers are indicative of an effective immunity to challenge and how long this immunity persists. The study could also evaluate
Of note is our finding that an additional (third) vaccination at day 42 resulted in a decrease in antibody titers a week later when only 1/6 animals remained with a high titer compared to $4 / 6$ animals which had high titers three weeks previously. There is no obvious explanation for this finding, but such decreases in antibody following toxoid vaccination in immune individuals have been reported previously [15]. Another possibility is that, since protein A binds with only $75 \%$ of IgG of llamas [16], the third vaccination stimulated an increase in an undetected isotype of IgG while decreasing levels of detectable isotypes. Changes in isotype have been reported post immunization [10] and this possibility appears to warrant further study.

The immune response we observed was only of short duration indicating the vaccine would need to be given frequently or strategically. Other adjuvants should be evaluated which might give high titers and longer duration responses. For example, a study could be performed using BSA emulsified with complete Freund's adjuvant in the first dose and with incomplete Freund's adjuvant in boosters [10]. Finally, challenge studies should be performed to establish whether vaccines protect against challenge and to determine a definitive vaccination scheme for llamas.

\section{Acknowledgements}

The authors wish to thank the Rosembusch Institute for technical support and for donating the vaccine; Florencia Testorelli, Tomás Puigdevall, Mariana Iglesias and Patricia Peirano for a critical reading of the manuscript; and the collaboration of Vet Federico 
Galigneana, Vet Facundo Durañona. We also wish to thank students Teresa Pinto, G. Perez Zabala, and Benjamín Uberti for collecting samples. This work was supported by a research grant from the International Foundation for Science (IFS B3069/1).

\section{References}

1. Davis R, Keeble E, Wright A, Morgan KL (1998) South American camelids in the United Kingdom: population statistics, mortality rates and causes of death. Vet Rec 142: 162-166.

2. Fowler ME (1998) Medicine and Surgery of South American camelids, 2nd edition. Iowa State: University Press, 589p.

3. Whitehead CE, Anderson DE (2006) Neonatal diarrhea in llamas and alpacas. Small Ruminant Research 61: 207-215.

4. Tibary A, Fite C, Anouassi A, Sghiri A (2006) Infectious causes of reproductive loss in camelids. Theriogenology 66: 633-647.

5. Bentancor A (2005) Estudio de la expresión de Antígenos de especies del Género Clostridium con Destino a Inóculos Vacunales. Tesis de Doctorado, Universidad Nacional de Buenos Aires. Buenos Aires, Argentina.

6. Rood JL, McClane BA, Songer JG, Titball RW (1997) The Clostridia: Molecular Biology and Phatogenesis, California, USA: Academic Press, 533p.

7. D'Alterio GL, Knowles TG, Eknaes EI, Loevland IE, Foster AP (2006) Postal survey of the population of South American camelids in the United Kingdom in 2000/01. Vet Rec 158: 86-90.

8. Sterne M, Bati I (1984) Pathogenic Clostridium. Ed. Acribia. Zaragoza. España.

9. Uzal FA, Bodero DA, Kelly WR, Nielsen K (1998) Variability of serum antibody responses of goat kids to a commercial Clostridium perfringens epsilon toxin. Veterinary Record 143: 472-474.

10. De Simone EA, Saccodossi N, Ferrari A, Leoni J (2008) Development of ELISAs for the measurement of IgM and
IgG subclasses in sera from llamas (Lama glama) and assessment of the humoral immune response against different antigens. Veterinary Immunology and Immunopathology 126: 64-73.

11. Hamers-Casterman C, Atarhouch T, Muyldermans S, Robinson G (1993) Naturally occurring antibodies devoid of light chains. Letters to Nature 363: 446-448.

12. Pfahler W, Bisesti E, Pereyra JB, Iribarren F (1998) Enzyme linked immunosorbent assay for potency testing of vaccines containing Clostridium perfringens type D epsilon-toxoid. Zentralbl Veterinarmed B 45: 133-9.

13 Nguyen VK, Desmyter A, Muyldermans S (2001) Functional heavy-chain antibodies in Camelidae. Adv Immunol 79: 261296.

14. Pugh DG, Wrightb J, Rowec S (1995) Serologic response of llamas next term to a commercially prepared leptospirosis vaccine. Small Ruminant Research 17: 193-196.

15. Danilova E, Shiryayev A, Kristoffersen EK, Sjursen H. (2005) Attenuated immune response to tetanus toxoid in young healthy men protected against tetanus. Vaccine 23: 49804983.

16. Hutchison JM (1995) Prospective characterization of the clinicopathologic and immunologic features of an immunodeficiency syndrome affecting juvenile llamas. Vet Immunol Immunopathol 49: 209-227.

\section{Corresponding author}

Dr. Adriana B. Bentancor

Facultad de Ciencias Veterinarias, Universidad de Buenos Aires Chorroarín 280, Ciudad Autónoma de Buenos Aires, Argentina Tel.:+54- 11- 4524- 8421

Email: aben@fvet.uba.ar

Conflict of Interest: No conflict of interest is declared 